\title{
Good manufacturing practices of artisanal products in Northeastern Brazil
}

\author{
*Medeiros, J. M. S. de, Câmpelo, M. C. S. and Silva, J. B. A. da. \\ Laboratório de Inspeção de Produtos de Origem Animal, Departamento de Ciências Animais, \\ Universidade Federal Rural do Semi-Árido, Av. Francisco Mota, n. 572, 59600-000, Mossoró, Rio \\ Grande do Norte, Brazil
}

\begin{abstract}
Article history:
Received : 12 April 2017 Received in revised form 18 May 2017

Accepted : 19 May 2017

Available Online :

25 May 2017
\end{abstract}

\section{Keywords:}

Artisanal production,

Good practices,

Food identity,

Culture

\section{DOI:}

http://doi.org/10.26656/ fr.2017.4.050

\begin{abstract}
This review provides an overview of the importance of good manufacturing practices in the elaboration of artisanal products, aiming to generate a discussion about this subject. The elaboration of artisanal food has been gaining prominence in several countries of the world since these products carry the identity and culture of a place. The traditional and artisanal way of manufacturing provides the food with a variation in its characteristics, which makes it peculiar in comparison to its similar, pleasing the most diverse demands of consumers. In addition, they are considered healthier and natural foods. In the Northeast of Brazil, these products are highlighted by the significant commercialization, being sources of income generation for the region. Among the most prominent products are the coalho and butter types cheeses, bottled butter and carne de sol. Despite the economic and cultural importance of these products, the traditional way of manufacturing, without proper hygiene care, can be a limiting factor for the formal commercialization of these products. Therefore, adopting good manufacturing practices at artisanal food processing places may be the first step towards the production of higher quality products that meet the requirements of the legislation but retain their artisanal manufacturing characteristics.
\end{abstract}

\section{Introduction}

Artisanal products are foods manufactured in a traditional way and that maintain the characteristics of their manufacturing regions. On the European continent they are highly valued, and nowadays in several regions of the world, the interest in these products has increased because of their traditions and qualities and for reducing the exodus to the great urban centers. In the European Union, these products have special seals and this has been driving the improvement of their quality (Ferreira and Ferreira, 2011).

The artisanal practice of manufacturing represents a great economic and social importance because, in addition to generating income for the local populations, it establishes a link with the traditions and a proximity between farmers, sellers, and consumers. In Brazil, artisanal cheeses have been highlighted, as they are products of great commercialization and acceptance, such as the Serrano, Caipira, Minas Artesanal and artisanal northeastern cheeses (Menezes, 2011a).

In addition to cheese, Brazil has other products and foods made in the artisanal way that maintain the traditional manufacturing characteristics of their regions and which has been gaining prominence among consumers. Among these products are wines and sparkling wines (Vale dos Vinhedos - Rio Grande do Sul), brandy (Paraty - Rio de Janeiro), coffee (Serra da Mantiqueira - Minas Gerais), traditional sweets (Pelotas - Rio Grande do Sul), the red propolis and extract (Manguezais de Alagoas - Alagoas), among others, distributed in several regions of Brazil (Silva et al., 2012a).

Among the artisanal products manufactured in the Northeast, the coalho and butter cheeses, the bottled butter, the cream butter and the carne de sol stand out (Menezes, 2011b). These products have a rudimentary manufacturing technology based on traditional and non-standard manufacturing methods that can compromise the hygienic-sanitary quality of the products (Miranda and Barreto, 2012).

Artisanal foods when prepared in poor hygienic conditions by untrained handlers with dubious raw materials and in environments with poorly sanitized utensils and equipment may be more likely to be contaminated. In artisanal manufacturing, aspects such as the hygiene of the product, utensils and equipment become even more important for the 
manufacture of a safe food, in addition it is highlighted the use of packages that do not have adequate sealing and are not sterile being a source of contamination (Venquiaruto et al., 2013).

On the other hand, the adoption of good practices in food manufacturing places aims to reduce the contamination of these products and to guarantee their quality, as well as to improve the acceptance by the consumers, being recommended in all places that manipulate food (Belli et al., 2013). Due to the way artisanal foods are manufactured, without proper hygiene care, the adoption of good practices becomes even more important in order to guarantee the quality of these products, as well as their insertion in the formal market.

In light of this context, this article presents a review on the adoption of good manufacturing practices in the elaboration of artisanal products in the Brazilian Northeast, aiming to instigate the discussion about the importance of these foods for the regional economy and culture, as well as the importance of their safe manufacture, through the presentation of data coming from works that approach this subject and were published in the last five years until the present year (2011-2016), with the exception of the normative presented.

\section{Artisanal products and their economic and cultural importance}

The manufacturing of artisanal foods is part of the food and nutritional security context because they are foods that maintain cultural and regional manufacturing characteristics and that, although they are often out of the hygienic sanitary standards, are considered by consumers as natural foods because of the less usage of industrialized substances and chemical preservatives (Gazolla, 2014).

Artisanal products have peculiarities when compared to their similar industrial ones concerning the variety of their constituents and their outstanding nutritional value, which makes it preferable for a portion of the consumers (Waldman and Kerr, 2015).

In a study carried out in São José do Rio Preto, São Paulo, when conducting interviews with consumers of milk and dairy products, the authors found that $31.18 \%(251 / 805)$ and $83.47 \%(672 / 805)$ preferred to buy, respectively, milk and cheese directly from the producers, claiming that "unprocessed" products are healthier, tastier and have lower prices (VidalMartins et al., 2013). Thus, underlining that a portion of consumers shows a preference for artisanal foods.

It can be observed that artisanal production is also based on a relationship of proximity between producer and consumer and that it is based on the appreciation of the recognition of the traditional form of production and the quality of the foods (Menezes, 2013).

The artisanal production presents a great contribution to the knowledge and dissemination of the characteristics of a region, spreading its culture and its peculiarities, besides playing a great participation in the economy of the region (Mckitterick et al., 2016). An example of an artisanal food that contributes to the generation of local income is the butter produced artisanally in the Rio Grande do Sul (RS), as well as in the Rio Grande do Norte (RN). In the RS, this production is the subsistence form for many families, as it is a fundamental ingredient in several traditional recipes (Venquiaruto et al., 2013).

Another important aspect is that traditional products provide consumers with options of products with a differentiated quality, due to variations in the characteristics of these foods (Cruz and Menasche, 2014). Among these products are the artisanal cheeses, such as the Minas Artesanal cheese, which despite being culturally manufactured in a region of Minas Gerais and having its own characteristics, presents a great variation of its constituents when analyzing cheeses of different producers, which shows the variation of techniques used by each producer and ensures a greater competitiveness between products with their own characteristics (Oliveira et al., 2013).

The artisanal production of some foods in Brazil is already regulated. We can cite as an example the Law No. 20.549 of 18 December 2012, which establishes the production and marketing of artisanal cheeses in Minas Gerais (Minas Gerais, 2012), as well as the Normative Instruction No. 16, dated 23 June 2015, laying down rules for the control and health inspection of products of animal origin (fish and products thereof, milk and dairy products, eggs and derived and products of bees and their byproducts) for small-scale agro-industries, which comprise establishments of family farmers which are characterized by the artisanal manufacture of food (Brasil, 2015).

Regarding the manufacture of the artisanal minas cheese, the existing regulations, despite being a way for the safe manufacture of the product, are seen as obstacles to the commercialization of the product and it is necessary that governmental institutions strive to recognize the importance of the participation of the sectors involved in the manufacture of this product and in the updating of existing standards, thus ensuring that minas cheese, considered a national patrimony, has its regulations updated so as to maintain its own peculiarities and characteristics (Dores and Ferreira, 2012). 
Considering the economic and cultural importance of artisanal products, there is a need to value this form of production as a strategic form for the use of local resources by producers, which promotes the movement of capital within the territory and strengthens the local economy. As such, the incentive to produce artisanal food should be part of the rural development policies in order to enable the local producer to produce products of guaranteed quality and with their regional characteristics (Menezes, 2013).

\section{Artisanal products of Northeastern Brazil}

One of the artisanal products manufactured in the Northeast and that presents commercialization at the national level is the coalho cheese. This cheese is mostly produced in small properties, through techniques that are passed down through generations and which present particularities among the various producers (Silva et al., 2012b). Its form of production and characteristics are regulated by the Normative Instruction No. 30 of 2001, Annex II (Brasil, 2001).

Another artisanal product that stands out in the economy of the Northeast region is the butter cheese or curd cheese. In this region, the production of this cheese together with the coalho cheese corresponds to 25 tons per month, being a characteristic product of the region Serido of Rio Grande do Norte (Freitas et al., 2013; Guimarães Filho and Silva, 2014). Annex III of Normative Instruction No. 30 of 2001, presents the standards of identity and quality of the butter cheese and regulates its production (Brasil, 2001). However, the aforementioned regulations do not cover the production of cheeses in the traditional way, which does not allow small producers, who are responsible for most of the production, to enter the formal market.

The bottled butter is defined as the greasy product that is presented in liquid or pasty state, coming from the cream of the milk, where almost all water is eliminated through the technological process (Brasil, 2001). This product is regulated; however, its regulations are focused on the industrial manufacture of the product, which does not correspond to the reality of its manufacture in the Northeastern states. Its largest production is carried out in the traditional way in small properties, being a source of income for small producers (Mottin et al., 2016).

The carne de sol is another traditional product of the Northeast, being this region considered the origin of its production and where there is an expressive commercialization of the product that has expanded to other regions of Brazil. There is no technical regulation for the manufacture of this product, which provides a great variation in the characteristics of the carne de sol, when analyzing products from different locations, besides being a barrier to its commercialization (Souza et al., 2015).

The artisanal foods produced in the Northeast region of Brazil is widely accepted by consumers and drives the economy of their manufacturing places. However, they are products that require normative that regulate their production and guarantee the commercialization of quality products.

\section{Concept and regulation of good manufacturing practices}

According to the Resolution 216, of 15 September 2004, good practices refer to all operations that must be adopted by places that participate in any elaboration stage in order to guarantee the hygienic sanitary quality of the food, in accordance with the current legislation (Brasil, 2004).

In Brazil, there are several regulations that regulate good manufacturing practices in several sectors of food production. These include the Resolution No. 216 of 15 September 2004 and the Resolution No. 275 of 21 October 2002, which present the Technical Regulation of Good Practices for Food Services, and establish the requirements for Standard Operating Procedures and Checklist of Good Practices for establishments that produce or industrialize food, respectively (Brasil, 2002, 2004). The Ministry of Agriculture, Livestock, and Food Supply also has documents that regulate Good Practices, such as ordinance 368 of 4 September 1997, which approves the technical regulation on hygienic-sanitary conditions and good manufacturing practices for establishments that elaborate and industrialize food (Brasil, 1997).

All food producing places must follow the minimum requirements, based on good manufacturing practices to ensure the quality of the food produced, and to ensure this quality, the handlers present themselves as the main factor that must be qualified and be aware of the associated risks to their activity, since in many places of food manufacturing it is observed the ignorance of the manipulators on the appropriate conduits for manipulation (Devides et al., 2014).

The implementation of Good Practices in foodproducing locations promotes improvements in product quality as well as behavioral changes within the work environment, where the food handler is aware of its key role in the safe production of a food and how this is Important for consumer health (Dias et al., 2012). 
Qualification and continued training are essential tools to minimize the risks of contamination of a food and to improve its quality. It should be emphasized that Good Practices should address all stages of food manufacturing and involve the general hygiene and organization of all materials and equipment that come into contact with the food during its production (Abdul-Mutalib et al., 2012).

\section{Artisanal production and application of good practices}

In the rural environment and in the production of artisanal products Good Practices are fundamental to assure the proper use of natural resources, allowing the production of high standard and proven quality products, the safe consumption of these products as well as to adding value to the product (Dores and Ferreira, 2012). One of the most important points in units that produce food in the traditional way is the orientation and qualification of the manufacturers so that they are aware of the hygienic-sanitary methods that must be adopted in the production of the food (Senger and Bizanni, 2011).

Some studies point to the unsatisfactory microbiological quality of products manufactured in the Northeast Brazil due to the precarious manufacturing conditions and present as a discussion the need and importance of adopting good manufacturing practices as a way to improve the quality of these products. Table 1 presents a summary of papers published in recent years that deal with the evaluation of the quality of artisanal products.

Encouraging the search for municipal, state and federal seals has been presented as a way to encourage artisanal food producers to improve the quality of their products and to guarantee the formal commercialization of their food. Other strategies, more common in European countries, are the Geographical Indication and the Denomination of Protected Origin that are ways of conserving the traditional form of manufacture of a product, preserving its peculiar characteristics, but guaranteeing its quality (Ferreira and Ferreira, 2011).
Table 1. Research related to the microbiological quality of artisanal products of the Brazilian Northeast, published between 2011-2016

\begin{tabular}{|c|c|c|}
\hline $\begin{array}{l}\text { Artisanal } \\
\text { product of } \\
\text { the Brazilian } \\
\text { Northeast }\end{array}$ & Results found & Reference \\
\hline Coalho cheese & $\begin{array}{l}\text { Coliform counts at } 45^{\circ} \mathrm{C} \text { and } \\
\text { Staphylococcus coagulase } \\
\text { positive greater than what is } \\
\text { established by the legislation }\end{array}$ & $\begin{array}{l}\text { Freitas et } \\
\text { al., } 2013\end{array}$ \\
\hline Coalho cheese & $\begin{array}{l}\text { Presence of thermotolerant } \\
\text { coliforms in } 100 \% \text { of } \\
\text { samples in quantities greater } \\
\text { than what is allowed }\end{array}$ & $\begin{array}{l}\text { Dantas et } \\
\text { al., } 2013\end{array}$ \\
\hline Butter cheese & $\begin{array}{l}\text { Presence of Salmonella sp. } \\
\text { and high counts of coagulase } \\
\text { positive Staphylococcus and } \\
\text { coliforms at } 45^{\circ} \mathrm{C}\end{array}$ & $\begin{array}{l}\text { Alexandre } \\
\text { et al., } 2016\end{array}$ \\
\hline Bottled butter & $\begin{array}{l}\text { Counts higher than what is } \\
\text { established by legislation for } \\
\text { coliforms at } 45^{\circ} \mathrm{C}\end{array}$ & $\begin{array}{l}\text { Venquiaruto } \\
\text { et al., } 2013\end{array}$ \\
\hline Carne de sol & $\begin{array}{l}\text { High incidence of coagulase } \\
\text { positive Staphylococcus }\end{array}$ & $\begin{array}{l}\text { Souza et al., } \\
2015\end{array}$ \\
\hline Carne de sol & $\begin{array}{l}\text { Presence of Salmonella sp. } \\
\text { and counts higher than what } \\
\text { is established by legislation } \\
\text { for Staphylococcus aureus }\end{array}$ & $\begin{array}{l}\text { Gurgel et } \\
\text { al., } 2014\end{array}$ \\
\hline Curd cheese & $\begin{array}{l}\text { Unsatisfactory } \\
\text { microbiological quality, } \\
\text { and physical-chemical } \\
\text { parameters and labeling } \\
\text { in disagreement with } \\
\text { the requirements of the } \\
\text { legislation }\end{array}$ & $\begin{array}{l}\text { Soares et } \\
\text { al., } 2013\end{array}$ \\
\hline
\end{tabular}

\section{Conclusion}

The artisanal production of a food presents great economic and cultural importance, guaranteeing the subsistence of several families, as well as the movement of income within regions. This form of manufacturing safeguards the traits of the identity of a region and allows the sustainable use of many natural resources. On the other hand, it is an empirical form of production and often does not guarantee the hygienic quality of the elaborated product, being a source of risk for the consumer. Government incentives should be created to reduce barriers to the safe manufacture of food, while maintaining traditional manufacturing characteristics. 


\section{References}

Abdul-Mutalib, N., Abdul-Rashid, M., Mustafa, S., AminNordin, S., Hamat, R. A. and Osman, M. (2012). Knowledge, attitude and practices regarding food hygiene and sanitation of food handlers in Kuala Pilah, Malaysia. Food Control, 27, 289-293.

Alexandre, A.P.S., Aquino, A.B., Lyra, D.G. de and Froehlich, A.(2016). Queijo manteiga - contaminação microbiológica e risco à saúde do consumidor. Revista Brasileira de Medicina Veterinária, 38(2), 121-124.

Belli, P., Cantafora, A.F.A., Stella, S., Barbieri, S. and Crimella, C. (2013). Microbiological survey of milk and dairy products from a small scale dairy processing unit in Maroua (Cameroon). Food Control, 32, 366370 .

Brasil. (2001). Ministério da Agricultura, Pecuária e Abastecimento. Instrução Normativa no 30, de 26 de junho de 2001. Aprova os Regulamentos Técnicos de Identidade e Qualidade de Manteiga da Terra ou Manteiga de Garrafa; Queijo de Coalho e Queijo de Manteiga. Diário Oficial da União, p. 5-8, 16 de julho.

Brasil.(2015). Ministério da Agricultura, Pecuária e Abastecimento. Instrução Normativa $\mathrm{n}^{\mathrm{o}} 16$, de 23 de junho de 2015. Estabelece em todo o território nacional as normas específicas de inspeção e a fiscalização sanitária de produtos de origem animal, referentes às agroindústrias de pequeno porte. Diário Oficial da União, Seção 1, 24 de junho.

Brasil.(1997). Ministério da Agricultura, Pecuária e Abastecimento. Portaria $n^{\circ} 368$, de 04 de Setembro de 1997. Regulamento Técnico sobre as condições Higiênico-Sanitárias e de Boas Práticas de Fabricação para Estabelecimentos Elaboradores/ Industrializadores de Alimentos. Diário Oficial da União. Brasília, DF.

Brasil.(2002). Ministério da Saúde. Agência Nacional de Vigilância Sanitária. Resolução $n^{\circ} 275$, de 21 de outubro de 2002. Regulamento Técnico de Procedimentos Operacionais Padronizados aplicados aos Estabelecimentos Produtores/Industrializadores de Alimentos e a Lista de Verificação das Boas Práticas de Fabricação em Estabelecimentos Produtores/ Industrializadores de Alimentos. Diário Oficial da União, 23 de outubro.

Brasil.(2004). Ministério da Saúde. Agência Nacional de Vigilância Sanitária. Resolução n ${ }^{\circ} 216$, de 15 de setembro de 2004. Regulamento Técnico de Boas Práticas para Serviços de Alimentação. Diário Oficial da União, DF, 16 de setembro.

Cruz, F.T. and Menasche, R. (2014). Tradition and diversity jeopardised by food safety regulations? The Serrano Cheese case, Campos de Cima da Serra region, Brazil. Food Policy, 45, 116-124.

Dantas, D.S., Araújo, A.M., Santos, J.O., Santos, R.M.S. and Rodrigues, O.G.(2013). Qualidade microbiológica do queijo de coalho comercializado no município de Patos, Estado da Paraíba. Revista Agropecuária Científica no Semiárido, 9(3), 110-118.
Devides, G.G.G., Maffei, D.F. and Catanozi, M.P.L.M. (2014). Perfil socioeconômico e profissional de manipuladores de alimentos e o impacto positivo de um curso de capacitação em Boas Práticas de Fabricação. Brazilian Journal of Food Technology, 17(2), 166-176.

Dias, M.A.C., Sant'Ana, A S., Cruz, A.G., Faria, J.A.F., Oliveira, C.A.F. de. and Bona, E. (2012). On the implementation of good manufacturing practices in a small processing unity of mozzarella cheese in Brazil. Food Control, 24, 199-205.

Dores, M.T. and Ferreira, C.L.L.F. (2012). Queijo minas artesanal, tradição centenária: ameaças e desafios. Revista Brasileira de Agropecuária Sustentável, 2(2), 26-34.

Ferreira, É.G. and Ferreira, C.L.LF. (2011). Implicações da madeira na identidade e segurança de queijos artesanais. Revista do Instituto de Laticínios "Cândido Tostes", 66(381), 13-20.

Freitas, W.C., Travassos, A.E.R. and Maciel, J.F. (2013). Avalição microbiológica e físico-química de leite cru e queijo de coalho produzidos no estado da Paraíba. Revista Brasileira de Produtos Agroindustriais, 15(1), $35-42$.

Gazolla, M. (2014). Segurança alimentar e nutricional e agroindústrias familiares: políticas públicas e ações locais. Segurança Alimentar e Nutricional, 21(2), 527-540.

Guimarães Filho, C. and Silva, P.C.S. da. (2014). Indicação geográfica, uma certificação estratégica para os produtos de origem animal da agricultura familiar do semiárido. Revista Econômica do Nordeste, 45, 14123.

Gurgel, T.E.P., Bandeira, M.G.L., Abrantes, M.R., Sousa, E.S. de, Silvestre, K.S., Sakamoto, S.M. and Silva, J.B.A. da. (2014). Avaliação da qualidade da carnede-sol produzida artesanalmente. Revista do Instituto Adolfo Lutz, 73(2), 208-213.

Mckitterick, L., Quinn, B.,Mcadam, R. and Dunn, A. (2016). Innovation networks and the institutional actor-producer relationship in rural areas: The context of artisan food production. Journal of Rural Studies, 48,41-52.

Menezes, S.S.M. (2013). Alimentos identitários: uma reflexão para além da cultura. Geonordeste, 24(2), 120-136.

Menezes, S.S.M. (2011a). Queijo artesanal: identidade, prática cultural e estratégia de reprodução social em países da América Latina. Revista Geográfica da América Central Número Especial EGAL, 1-16.

Menezes, S.S.M. (2011b). Queijo de coalho: tradição cultural e estratégia de reprodução social na região Nordeste. Revista de Geografia, 28(1), 40-56.

Minas Gerais. (2012). Assembléia Legislativa do Estado De Minas Gerais. Lei $n^{\circ} 20.549$, 18 de dezembro de 2012. Dispõe sobre a produção e a comercialização dos queijos artesanais de Minas Gerais. Diário do Executivo. Minas Gerais, Belo Horizonte, 19 de dezembro. 
Miranda, P.C. and Barreto, N.S.E. (2012). Avaliação higiênico-sanitária de diferentes estabelecimentos de comercialização da carne-de-sol no município de Cruz das Almas-BA. Revista Caatinga, 25(2), 166-172.

Mottin, V.D., Pimentel, V.J.F., Damásio, J.M.A., Silva, R.B. and Vieira, V.F.(2016). Escherichia coli e Staphylococcus aureus em manteiga de garrafa comercializada na região Sudoeste da Bahia. C\&DRevista Eletrônica da Fainor, 9(1), 191-197.

Oliveira, D.F. de, Porto, M.A.C., Bravo, C. E. C. and Tonial, I.B.(2013). Caracterização físico-química de queijos minas artesanal produzido em diferentes microrregiões de Minas Gerais. Revista Brasileira de Economia Doméstica, 24(2), 185-196.

Senger, A.E.V. and Bizani, D. (2011). Pesquisa de Staphylococcus aureus em queijo minas frescal, produzido de forma artesanal e industrial, comercializado na cidade de Canoas/RS, Brasil. Revista de Ciências Ambientais, 5(2), 25-42.

Silva, F.N., Anjos, Flávio S., Caldas, Nádia V. and Pollnow, G.E. (2012a). Desafios a institucionalização das indicações geográficas no Brasil. DRd Desenvolvimento Regional em debate, 2(2), 31-44.

Silva, R.A., Bismara, P.A., Moura, R.B., Lima Filho, J.L., Porto, A.L.F. and Cavalcanti, M.T.H. (2012b). Avaliação da microbiota bacteriana do queijo de coalho artesanal produzido na região Agreste do estado de Pernambuco. Arquivos Brasileiros de Medicina Veterinária e Zootecnia, 64(6), 1732-1738.

Soares, K.M., Góis, V., Silva, J.B.A. and Bezerra, N.M. (2013). Qualidade do creme de leite artesanal. Semina: Ciências Agrárias, 34(6), 2937-2944.

Souza, D.R. de., Almeida, A.C. de., Souza, R.M. de., Jesus, C.A. de. and Raidan, F.S.S. (2015). Qualidade microbiológica de cortes cárneos utilizados para elaboração de carne de sol no Norte de Minas Gerais submetidos a diferentes tecnologias de conservação. Revista Brasileira de Ciência Veterinária, 22(3-4), 211-215.

Venquiaruto, L.D., Dallago, R.M., Santos, D., MarcielI, P. and Toledo, J. (2013). Avaliação microbiológica de manteigas artesanais comercializadas na cidade Tapejara/RS. Revista Perspectiva, 37(139), 19-25.

Vidal-Martins, A.M.C., Bürger, K.P., Gonçalves, A.C.S., Grisólio, A.P.R., Aguilar, C.E.G. and Rossi, G.A.M. (2013). Avaliação do consumo de leite e produtos lácteos informais e do conhecimento da população sobre os seus agravos à saúde pública, em um município do estado de São Paulo, Brasil. Boletim de Indústria Animal, 70(3), 221-227.

Waldman, K.B. and Kerr, J.M. (2015). Is Food and Drug Administration policy governing artisan cheese consistent with consumer's preferences? Food Policy, $55,71-80$. 